bone must in some way be inhibited by mithramycin. There is some evidence that parathyroid hormone also has an anabolic effect on bone, and Kalu et al. (1970) demonstrated a $23.5 \%$ increase in bone calcium, a $21 \%$ increase in stable hydroxyproline, and a $12.9 \%$ increase in incorporation of ${ }^{3} \mathrm{H}$ proline into bone hydroxyproline in thyroparathyroidectomized rats treated with parathyroid hormone. This anabolic effect of parathyroid hormone on bone may be of importance if its destructive effect is simultaneously blocked by mithramycin.

The metabolic effects of mithramycin on calcium and phosphorus metabolism appear to be similar to those of calcitonin, which is known to be of therapeutic use in Paget's disease of bone. Calcitonin, like mithramycin, inhibits bone resorption and reduces plasma calcium in patients with Paget's disease of bone (Bijvoet et al., 1968). There is presumably increased production of parathyroid hormone secondary to calcitonin-induced hypocalcaemia, and it may well be that both mithramycin and calcitonin exert their beneficial effect in Paget's disease of bone by a similar mechanism.

We are grateful to Dr. P. G. Walker and Professor C. E. Dent for their help and advice and to Dr. T. G. Lewis and Dr. D. A. Brewerton who referred patients to us. We also thank Pfizer Ltd. for supplying the mithramycin for this study.

\section{References}

Albright, F., and Henneman, P. H. (1955). Transactions of the Association of American Physicians, 68, 238

Albright, F., and Reifenstein, E. C. (1948). The Parathyroid Glands and Metabolic Bone Disease, p. 284. Baltimore, Williams and Wilkins.

Avioli, L. V., and Berman, M. (1968). Fournal of Clinical Endocrinology and Metabolism, 28, 700 .

Barnicot, N. A. (1948). Fournal of Anatomy (London), 82, 233.

Bernstein, D., Kleeman, C. R., and Maxwell, M. H. (1963). Proceedings of the Society for Experimental Biology and Medicine, 112, 353.

Bijvoet, O. L. M., Van der Sluys Veer, J., and Jansen, A. P. (1968). Lancet, $1,876$.

Curreri, A. R., and Ansfield, F. J. (1960). Cancer Chemotherapy Reports, $8,18$.

Goldberg, I. H. (1965). American fournal of Medicine, 39, 722

Higgins, B. A., Nassim, J. R., Alexander, R., and Hilb, A. (1965). British Medical fournal, 1, 1159.

Jacobsen, M., Holmes, R., Peterson, J., and Engbring, N. (1965). Clinical Research, 13, 324.

Kalu, D. N., Doyle, F. H., Pennock, J., Denys-Matrajt, H., and Foster, G. V. (1970). Calcified Tissue Research, Suppl. to vol 4, p. 72 .

Kind, P. R. N., and King, E. J. (1954). Fournal of Clinical Pathology, 7, 322.

Kleeman, C. R., Rockney, R. E., and Maxwell, M. H. (1958). Yournal of Clinical Investigation, 37, 907 .

Koevoet, A. L. (1965). Clinica Chimica Acta, 12, 323.

Kofman, S., and Eisenstein, R. (1963). Cancer Chemotherapy Reports, 32, 77.

Parker, G. W., Wiltsie, D. S., and Jackson, C. B., jun. (1960). Cancer Chemotherapy Reports, 8,23 .

Parsons, V., Baum, M., and Self, M. (1967). British Medical fournal, 1, 474

Ryan, W. G., Schwartz, T. B., and Perlia, C. P. (1969). Annals of Internal Medicine, 60, 549 .

Trudeau, D. L., and Freier, E. F. (1967). Clinical Chemistry, 13, 101.

Walker, P. G., and Collins, J. A. (1963). Bone Metabolism in Relation to Clinical Medicine, ed. H. A. Sissons. London, Pitman Medical.

Yarbo, J. W., Kennedy, B. J., and Barnum, C. P. (1966). Cancer Research, 26, 36 .

\title{
Effect of Actinomycin D on Paget's Disease of Bone
}

\author{
JAMES J. FENNELLY, JOSEPH F. GROARKE
}

\section{British Medical fournal, 1971, 1, 423-426}

\section{Summary}

Four patients with active Paget's disease were treated with the RNA inhibitor actinomycin D. Three were clinically improved after treatment; the fourth had multiple collapsed vertebrae and showed no symptomatic improvement. Striking changes took place in urinary calcium and hydroxyproline, in serum alkaline phosphatase, and to a less extent in serum calcium and phosphate. These studies are continuing and are being compared with the effects of mithramycin.

\section{Introduction}

The RNA inhibitors best known in clinical use are mithramycin and actinomycin $D$. Both are derived from species of Streptomyces, and their most important place in medicine has been in the treatment of various testicular and renal tumours (Tan et al., 1959; Brown and Kennedy, 1965). They are thought to exert their action by binding with the DNA chain, preventing RNA reduplication and thus blocking the synthesis of proteins and enzymes (Kirk, 1960).

It was noted during the trials of mithramycin that among its side effects hypocalcaemia was prominent (Parsons et al., 1967). This prompted Ryan and Schwartz (1969) to study the

St. Vincent's Hospital and University College, Dublin 6 JAMES J. FENNELLY, M.D., M.R.C.P.I.

JOSEPH F. GROARKE, M.B., B.CH. effects of mithramycin in Paget's disease of bone. Their results indicate an improvement in the biochemical and clinical signs of the condition. They concluded that the effect of actinomycin D is "slight and transient," though no figures were quoted.

The purpose of this communication is to present four cases of Paget's disease treated with actinomycin $\mathbf{D}$.

\section{Patients and Methods}

The salient features of the four patients treated are shown in Table I. The three women were postmenopausal; the other

TABle I-Clinical Features of Patients with Paget's Disease

\begin{tabular}{|c|c|c|c|c|c|}
\hline $\begin{array}{l}\text { Case } \\
\text { No. }\end{array}$ & Age & Sex & Distribution & $\begin{array}{l}\text { Alk. } \\
\text { Phos. }\end{array}$ & Symptoms \\
\hline $\begin{array}{l}1 \\
2 \\
3 \\
4\end{array}$ & $\begin{array}{l}65 \\
62 \\
47 \\
75\end{array}$ & $\begin{array}{l}\mathrm{F} \\
\mathrm{F} \\
\mathrm{M} \\
\mathrm{F}\end{array}$ & $\begin{array}{l}\text { Skull, spine, pelvis } \\
\text { Left pelvis } \\
\text { Skull, spine, pelvis } \\
\text { Skull, spine }\end{array}$ & $\begin{array}{r}120 \\
57 \\
320 \\
306\end{array}$ & $\begin{array}{l}\text { Back pain and deafness } \\
\text { Leg pain } \\
\text { Back pain } \\
\text { Headache, buzzing, deafness }\end{array}$ \\
\hline
\end{tabular}

patient was a 47-year-old bachelor. All had complaints of bone pain related to Paget's disease and were in hospital. They were maintained on a general ward diet which did not contain an excess of gelatin. Full blood counts and serum enzyme studies (serum aspartate aminotransferase, serum alanine aminotransferase, and serum lactate dehydrogenase) were carried out during treatment and for several weeks afterwards. Actinomycin $\mathrm{D}$ was administered into the tubing of a $5 \%$ dextrose infusion to a total dose of $2,500 \mu \mathrm{g}$ over three to five days. Twenty-four-hour collections of urine were 
carried out under toluene. Serum and urinary calcium concentrations were estimated by the method of Trinder (1960). Serum and urinary phosphate concentrations were estimated by the method of Delsal and Manhouri (1958). Serum alkaline phosphatase was measured by the method of King and Armstrong. Heat and urea stability of the enzyme throughout the study showed characteristics of skeletal phosphatase (Fennelly et al., 1969). Urinary hydroxyproline content was estimated by the method of Prockop and Udenfriend (1960).

\section{Results}

Biochemical results of drug administration are given in Table II, while changes in individual patients are shown in Figs. 1 to 4. Because of renal insufficiency, and coincidental use of diuretics, urinary excretion levels of calcium and hydroxy-

TABLE II-Changes in Serum Calcium (S.Ca.), Serum Phosphate (S.Ph.), Serum Alkaline Phosphatase (S.A.P.), Urinary Calcium (U.Ca.), Urinary Phosphate (U.Ph.), and Urinary Hydroxyproline (U.OHP) in the Week before, during, and after Treatment

\begin{tabular}{|c|c|c|c|c|c|c|c|}
\hline & & & $\begin{array}{l}\text { Case } \\
\text { No. }\end{array}$ & Pre- $\mathrm{R}$ & $\mathbf{R}$ & $\begin{array}{l}\text { Post } \mathbf{R} \\
\text { Week } 1\end{array}$ & $\begin{array}{l}\text { Post R } \\
\text { Week 2 }\end{array}$ \\
\hline S.Ca. & $\cdots$ & .. & $\begin{array}{l}1 \\
2 \\
3\end{array}$ & $\begin{array}{l}10.5 \\
10.1 \\
11.7\end{array}$ & $\begin{array}{c}10 \cdot 3 \\
11 \\
9.6\end{array}$ & $\begin{array}{r}9.2 \\
10.6 \\
9.8\end{array}$ & $\begin{array}{l}9 \cdot 6 \\
10 \cdot 5 \\
10\end{array}$ \\
\hline S.Ph. &.. & .. & $\begin{array}{l}1 \\
2 \\
3\end{array}$ & $\begin{array}{l}4 \cdot 7 \\
3.7 \\
3.5\end{array}$ & $\begin{array}{l}3 \cdot 8 \\
3 \cdot 2 \\
3 \cdot 7\end{array}$ & $\begin{array}{l}2.5 \\
2.9 \\
3.4\end{array}$ & $\begin{array}{l}2 \cdot 7 \\
3 \cdot 1 \\
3 \cdot 9\end{array}$ \\
\hline S.A.P. & .. & .. & $\begin{array}{l}1 \\
2 \\
3\end{array}$ & $\begin{array}{c}109 \cdot 5 \\
46 \cdot 5 \\
300\end{array}$ & $\begin{array}{r}104 \cdot 4 \\
40 \cdot 2 \\
231 \cdot 5\end{array}$ & $\begin{array}{r}84 \cdot 4 \\
24 \cdot 2 \\
189\end{array}$ & $\begin{array}{c}73.9 \\
18.9 \\
222\end{array}$ \\
\hline U.Ca. & . & . & $\begin{array}{l}1 \\
2 \\
3\end{array}$ & $\begin{array}{l}241 \cdot 5 \\
156 \\
351\end{array}$ & $\begin{array}{l}190 \\
102 \cdot 2 \\
188\end{array}$ & $\begin{array}{r}40.9 \\
48.7 \\
105.5\end{array}$ & $\begin{array}{l}82.6 \\
46.5 \\
81.7\end{array}$ \\
\hline U.Ph. & .. & $\ldots$ & $\begin{array}{l}1 \\
2 \\
3\end{array}$ & $\begin{array}{l}866 \cdot 5 \\
1090 \\
907\end{array}$ & $\begin{array}{l}886 \\
950 \cdot 4 \\
1110\end{array}$ & $\begin{array}{l}508 \\
646 \cdot 8 \\
714\end{array}$ & $\begin{array}{l}712 \\
607 \\
105 \cdot 7\end{array}$ \\
\hline U.OHP & . & . & $\begin{array}{l}1 \\
2 \\
3\end{array}$ & $\begin{array}{c}252 \cdot 7 \\
78 \cdot 24 \\
430\end{array}$ & $\begin{array}{c}175 \cdot 8 \\
58 \\
178 .\end{array}$ & $\begin{array}{c}64 \cdot 2 \\
44 \\
143\end{array}$ & $\begin{array}{l}100 \cdot 9 \\
102\end{array}$ \\
\hline
\end{tabular}

proline were not valid in Case 4. There was a moderate transient reduction in serum calcium, with a clear-cut reduction in serum phosphate which lasted for one to two weeks. At the end of the course of treatment urinary hydroxyproline and calcium showed a sharp fall to $26 \%$ and $33 \%$ of baseline levels respectively; this fall lasted at least two weeks. Reduction in serum alkaline phosphatase developed more slowly, but continued for four weeks after treatment, to reach levels of about $65 \%$ of baseline.

Case 1.-A 68-year-old woman with a 12-year history of Paget's disease involving the skull, pelvis, and left hip region presented with shoulder and hip pain. After actinomycin D $500 \mu \mathrm{g}$ daily for five days there was considerable biochemical change but no relief of pain (Fig. 1). Twelve days after the first course actinomycin D $1,000 \mu \mathrm{g}$ daily for two days was given; leucopenia of $2,900 / \mathrm{mm}^{3}$ developed, resolving over the next week. Pain was much improved seven days after the last dose and did not return until 12 weeks later, at which time serum alkaline phosphatase and urinary calcium had returned almost to pretreatment levels. Biochemical changes consisted of a transient fall in serum calcium and inorganic phosphate, accompanied by an immediate and lasting fall in urinary calcium and hydroxyproline and a gradual persistent fall in serum alkaline phosphatase.

Case 2.-This patient (Fig. 2), a 62-year-old woman, had a twoyear history of left knee pain. The knee was radiologically normal, but there was an area of Paget's disease in the left side of the pelvis involving the hip joint, and it was thought that her pain was referred from here. Actinomycin D 2,500 $\mu \mathrm{g}$ was administered over three days; she was symptom-free five-days later, but pain returned after six weeks. At this stage she had two injections of actinomycin D $500 \mu \mathrm{g}$ with an eight-day interval; pain relief followed the second injection, but pain recurred four weeks later. A further injection of actinomycin D $500 \mu \mathrm{g}$ was given in the outpatient department; relief of pain followed within 24 hours and persisted for six weeks. Her serum alkaline phosphatase level dropped since first referral from 57 to 15 King-Armstrong units after the first course of actinomycin $D$; since then it has not exceeded 25 K.A. units over a total observation period of six months.

Case 3.-This patient (Fig. 3), a 47-year-old single man had a two-year history of pain in the back. $X$-ray examination showed marked Paget's disease of skull, pelvis, and spine, with partial collapse of the twelfth thoracic and fourth and fifth lumbar vertebrae. Serum alkaline phosphatase was 320 K.A. units, and urinary calcium and hydroxyproline were also raised at 335 and $266 \mathrm{mg}$ per 24 hours respectively, rising further after immobilization. He was treated with two courses of actinomycin D 2,500 $\mu \mathrm{g}$, each over five days with a 10-day interval. There was some improvement of back pain, associated with biochemical changes similar to those previously noted in Case 1 .

Toxicity.-The most troublesome side effects were nausea, vomiting, and depression. All, however, cleared rapidly after cessation of therapy.

Case 4.-A 74-year-old woman, with a 14-year history of Paget's disease localized to the skull, had impaired renal function with blood urea $60 \mathrm{mg} / 100 \mathrm{ml}$. When referred to us she was complaining of very severe headaches (Fig. 4). Her blood pressure was $210 / 40$ and she was in congestive cardiac failure. She had an easily palpable thrill and grade 4 bruit over the left temporal area. Cardiac failure was poorly controlled with digoxin, frusemide $80 \mathrm{mg}$. daily, and spironolactone $100 \mathrm{mg}$. daily. Because of the renal impairment and the use of frusemide, little reliance could be placed on her urinary levels (Tambyah and Lim, 1969). Serum alkaline phosphate was 306 K.A. units. She was treated with actinomycin D $2,500 \mu \mathrm{g}$ over five days, and five weeks later she was pain-free. Her cardiac failure was readily controlled with

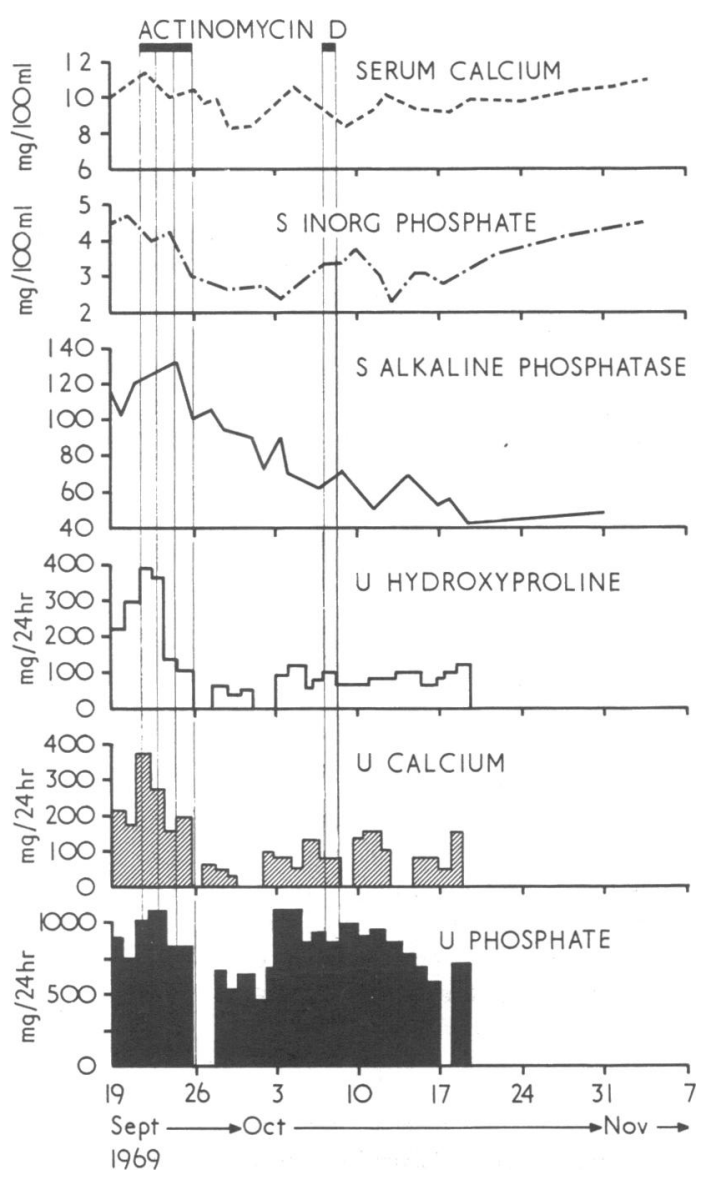

FIG. 1-Effect of actinomycin D on biochemical values in Paget's disease (Case 1). 


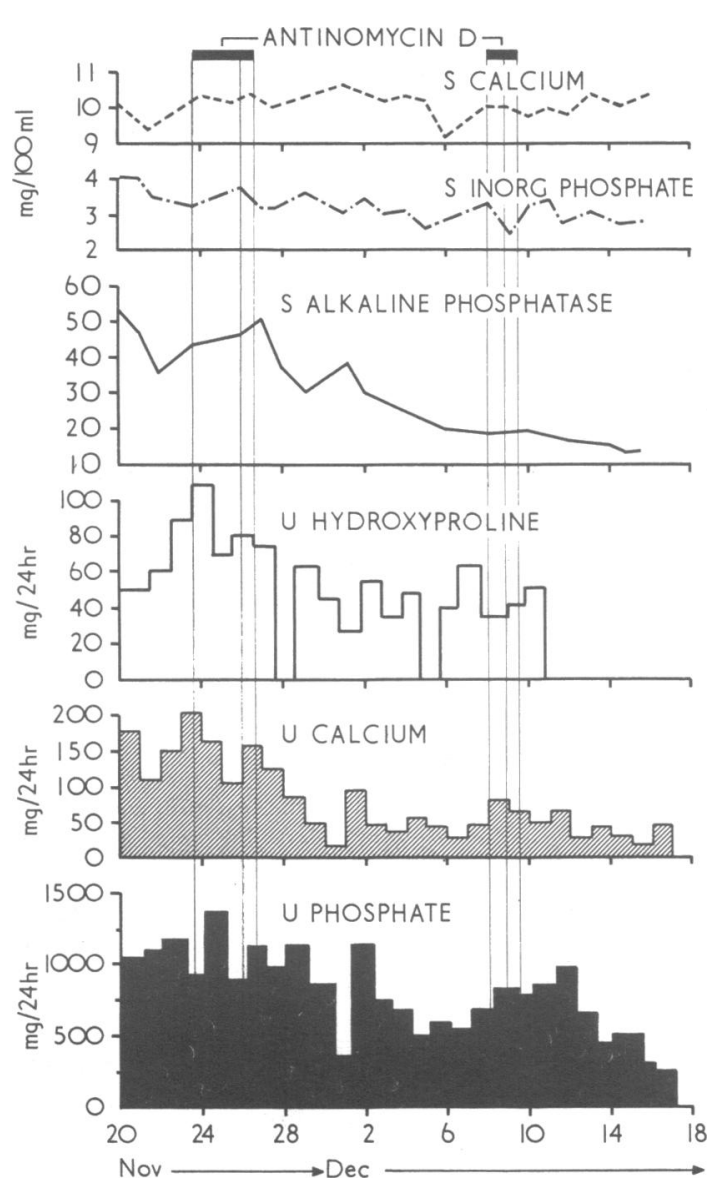

FIG. 2-Effect of actinomycin D on biochemical values in Paget's disease (Case 2).

digoxin, frusemide $40 \mathrm{mg}$, on alternate days, and spironolactone $50 \mathrm{mg}$ on alternate days. The left temporal bruit had dropped to grade 2 , the thrill was no longer palpable, and blood pressure was $150 / 60$. Serum alkaline phosphatase had fallen to $160 \mathrm{~K}$.-A. units

\section{Discussion}

The acute fall in urinary calcium and hydroxyproline persisted as long as the patients were followed in hospital. In the absence of treatment a continuing rise would have been expected in urinary calcium (Albright and Riefenstein, 1948). The fall in serum inorganic phosphate was quite pronounced but the fall in serum calcium was not as marked as that reported following treatment with mithramycin. This effect lasted five to seven days after the end of drug therapy. A delayed, gradual fall in serum alkaline phosphatase has been previously recorded in immobilized patients (Albright and Riefenstein, 1948); however, the effect persisted in our patients after discharge, and was prolonged in the one who received actinomycin $\mathrm{D}$ as an outpatient.

We are satisfied that the three women had a significant clinical improvement. The man had persistent back pain, but multiple collapsed vertebrae rendered continuing pain inevitable. The results produced by actinomycin $D$ resembled those produced by mithramycin and were similar to those reported by Ryan and Schwartz (1969). We are not yet certain that there is a striking difference in the duration of benefit from these drugs. The mechanism responsible for these changes remains uncertain. The fall in serum alkaline phosphatase levels would suggest decreased osteoblastic activity, while the reduction in urinary calcium excretion suggests diminished overall activity of Paget's process with reduction in osteolytic and osteoblastic activity.

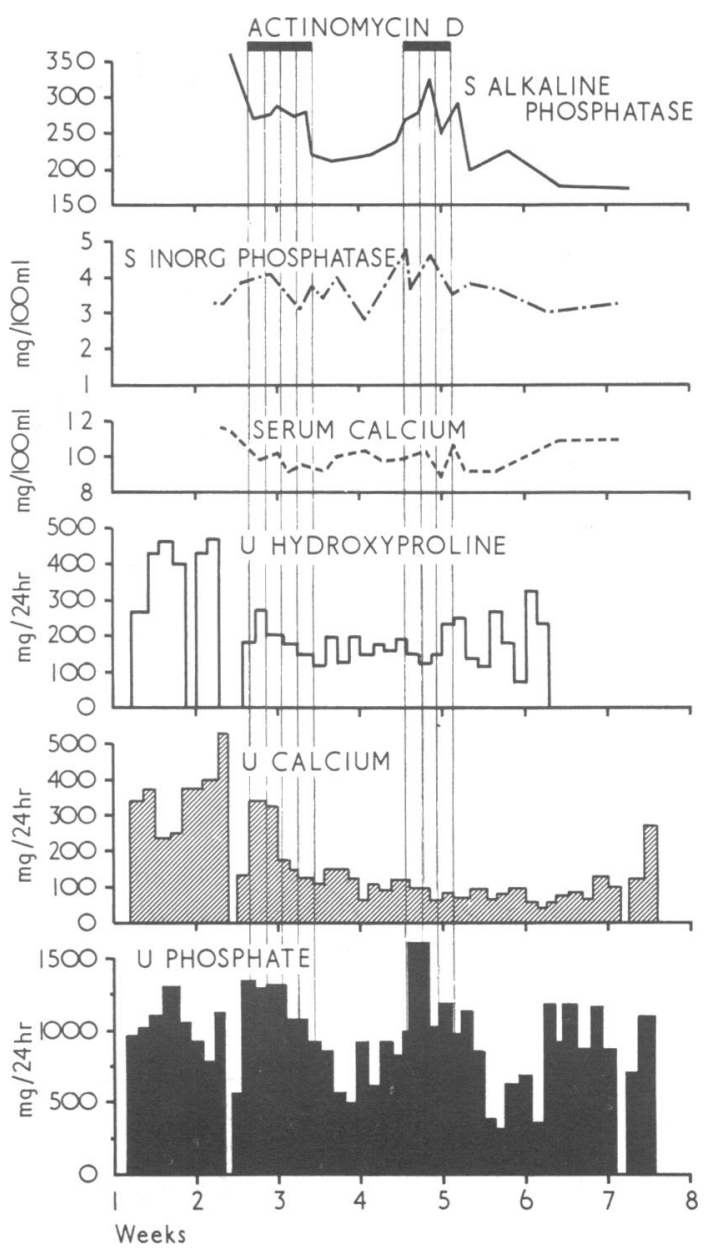

FIG. 3-Effect of actinomycin D on biochemical values in Paget's disease (Case 3).

The fall in urinary hydroxyproline level would support the concept of a reduced bone turnover. How these changes are brought about is unknown. Albright and Riefenstein (1948) documented a progressive fall in serum alkaline phosphatase in an immobilized patient with Paget's disease; the relative immobilization involved while in hospital may account for at least some of the fall seen in our patients. At the same time they showed that immobilization leads to progressively increasing hypercalcaemia; hydroxyproline excretion was not studied, but our patients, before treatment, tended to show a pronounced rise in both urinary hydroxyproline and urinary calcium. The reversal of this trend by RNA inhibitor drugs was striking.

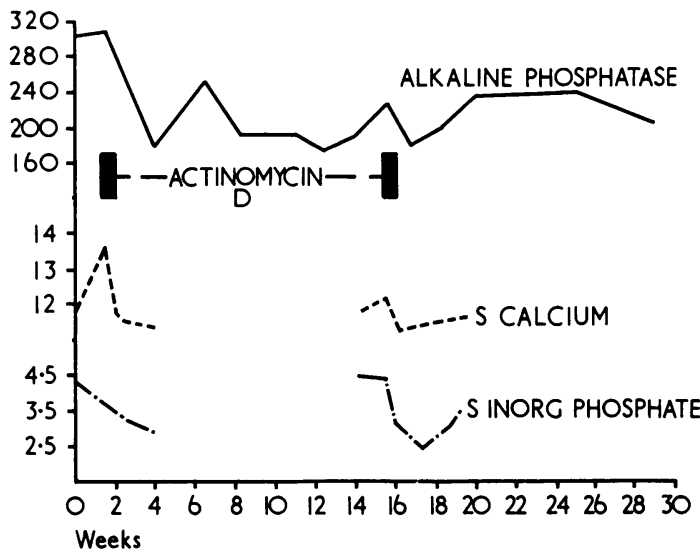

FIG. 4-Effect of actinomycin D on biochemical values in Paget's disease (Case 4). 
It is known that actinomycin D blocks the action of parathyroid hormone on bone (Eisenstein et al., 1964; Rasmussen et al., 1964) while not interfering with its actions on renal calcium and phosphate handling. Actinomycin D does not prevent secretion of parathyroid hormone (Tashjiian, 1965). It is possible that the RNA inhibitors act initially by preventing parathyroid hormone induced calcium release from bone, leading to a fall in serum calcium with a resulting increase in parathyroid hormone secretion. This extra parathyroid hormone (unable to act on bone) could be responsible for hypophosphataemia and hypocalciuria, by an action on tubular reabsorption. This aspect may be clarified somewhat by parathyroid hormone assay and studies of renal phosphate clearance.

The similarities between the effects of actinomycin D on our patients, and mithramycin (Ryan and Schwartz, 1969), and the actions of calcitonin in Paget's disease as described by Bijvoet and Jansen (1967) and Bijvoet et al. (1968), suggest that RNA inhibitors may act by potentiating or stimulating the action of calcitonin. Calcitonin assay may shed some light on this aspect.

A direct action of RNA inhibitors on osteoblasts appears quite likely, particularly in view of the findings of reduced formation of chondroitin sulphate in rats treated with actinomycin D (Hulth and Lindberg, 1968) and the finding of inhibition of bone growth in children treated with this agent for renal tumours (Aarskog and Hexeberg, 1968). However, the finding of such a pronounced fall in urinary calcium even after the serum calcium level has returned to normal suggests that a humoral mechanism is also likely to be involved. Actinomycin $\mathrm{D}$ is a toxic drug, a factor which must be a major one in the limitation of the use of this drug in Paget's disease, where long-standing treatment would be required.

\section{References}

Aarskog, A., and Hexeberg, A. (1968). Acta Paediatrica Scandinavica, 57, 463.

Albright, F., and Riefenstein, E. C. (1948). The Parathyroid Glands and Metabolic Bone Disease. Baltimore, Williams \& Wilkins.

Bijvoet, O. L. M., and Jansen, A. P. (1967). Lancet, 2, 471.

Bijvoet, O. L. M., Van der Sluys Veer, J., and Jansen, A. P. (1968). Lancet, 1,876 .

Brown, J. H., and Kennedy, B. J. (1965). New England fournal of Medicine, 272, 111 .

Delsal, J. L., and Manhouri, H. (1958). Bulletin de la Société de Chimie Biologique, 40, 1623.

Eisenstein, et al. (1964). Proceedings of the Society for Experimental Biology, 117,77 .

Fennelly, J. J., Dunne, J., McGeeney, K. F., Lee Chong, L., and Fitz-

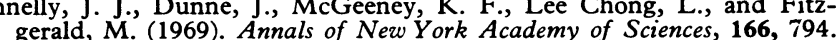
Hulth; A., and Lindberg, L. (1968). Acta Pathologica et Microbiologica Scandinavica, 73, 177 .

Kirk, J. M. (1960). Biochimica et Biophysica Acta, 52, 167.

Parsons, V., Baum, M., and Self, M. (1967). British Medical fournal, 1, 474. Prockop, D. J., and Udenfriend, S. (1960). Analytical Biochemistry, 1, 228 Rasmussen, H., Arnaud, C., and Hawker, C. (1964). Science, 154, 1019.

Ryan, W. G., and Schwartz, T. B. (1969). Annals of Internal Medicine, 70, 549 .

Tambyah, J. A., and Lim, M. K. L. (1969). British Medical fournal, 1, 751. Tan, C. T. C., Dargeon, H. W., and Burchenal, J. H. (1959). Pediatrics,

24, 544.
Tashiian, A. H. (1965). Endocrinology, 77, 375.

Trinder, P. (1960). Analyst, 85, 889.

\title{
Clinical Trial of Malaria Prophylaxis in Tropical Splenomegaly Syndrome
}

\author{
PIETER C. STUIVER, JOHN L. ZIEGLER, JOHN B. WOOD, RICHARD H. MORROW
} M. S. R. HUTT

\section{Introduction}

Tropical splenomegaly syndrome refers to chronic splenomegaly of uncertain cause which has been reported from a number of tropical countries (Pitney, 1968). In Uganda the syndrome was formerly known as "big spleen disease" and has been associated with lymphocytic infiltration of the hepatic sinusoids (Hamilton et al., 1965, 1966; Marsden et al., 1965). Malarial infection has been implicated in its aetiology on the basis of several kinds of indirect evidence. There is a close geographic coincidence of tropical splenomegaly syndrome with malarious areas, and patients having it show high titres of malaria antibodies (Gebbie et al., 1964; Hamilton et al., 1965; Marsden et al., 1967). Sickle-cell trait, which confers considerable protection against severe Plasmodium falciparum malaria, occurs rarely if at all in these patients (Hamilton et al., 1969). More compelling evidence is contained in the reports of improvement in hepatosplenomegaly and anaemia in patients with tropical splenomegaly syndrome following long-term malaria prophylaxis (Lowenthal and Hutt, 1968; Watson-Williams and Allan, 1968; Sagoe, 1970). In order to confirm these reports a double-blind randomized clinical trial using primaquine and chloroquine was carried out in 29 Ugandan patients with tropical splenomegaly syndrome. The results form the basis of the present report. 